\title{
Different States in Cd's Settlement Process at Temporal and Spatial Scales
}

\author{
Dongfang Yang ${ }^{1,2, a}$, Haixia Li ${ }^{1}$, Xiaolong Zhang ${ }^{1}$, Qi Wang ${ }^{1}$, Lianguo Zhao ${ }^{1}$ \\ ${ }^{1}$ Accountancy Shool, Xijing University, Xian 710123, China \\ ${ }^{2}$ North China Sea Environmental Monitoring Center, SOA, Qingdao 266033, China \\ adfyang_dfyang@126.com
}

Keywords: Cadmium (Cd); Settlement process; Temporal-spatial scale; State; Jiaozhou Bay

\begin{abstract}
Using investigation on Cd in surface waters in 1988 in Jiaozhou Bay, this paper analyzed the vertical changes of Cd contents in waters, defined the settlement processes of Cd contents at temporal and spatial scales. Results showed that in April 1988, in the outer side of the bay mouth, Cd contents in surface waters were higher than those in bottom waters, while in waters in the bay mouth Cd contents in surface waters were lower than in bottom waters. In July 1988, in the estuaries of the major inflow rivers in the northeast of the bay, the inner side of the bay mouth and the center of the bay, Cd contents in surface waters were higher than in bottom waters, while in waters in the southwest of the bay Cd contents in surface waters were lower than in bottom waters. During the settlement process of $\mathrm{Cd}$, there were three time states at temporal scale, and three space states at spatial scale. Taking time as $\mathrm{x}$-coordinate, and space as $\mathrm{y}$-coordinate, a block diagram model was provided to describe the time and space states. In general, there were nine states during the actual settlement process. According to the spatial-temporal settlement process of Cd, the law of spatial-temporal settlement process was revealed, the changes of Cd contents in surface and bottom waters were determined by the strength of the source input and the distance of the transport path.
\end{abstract}

\section{Introduction}

Cd is widely used in industry and agriculture. A great deal of Cd-containing products are commonly used [1-2] and the amount of Cd-containing wastes are increasing with the rapid development of economic and population size in the past several decades [3-4]. As a result, the surface waters of the ocean are polluted by Cd via atmospheric deposition, stream flow discharge etc. [5-10]. Jiaozhou Bay is a semi-closed bay located in Shandong Province, China. Using investigation on Cd in surface waters in 1988 in Jiaozhou Bay, this paper analyzed the vertical changes of Cd contents in waters, defined the settlement processes of Cd contents at temporal and spatial scales. The aim of this paper was to provide basis for research on the seasonal variation and horizontal migration of $\mathrm{Cd}$ in surface and bottom waters.

\section{Study area and data collection}

Jiaozhou Bay is located in the south of Shandong Province, eastern China $\left(35^{\circ} 55^{\prime}-36^{\circ} 18^{\prime} \mathrm{N}\right.$, $120^{\circ} 04^{\prime}-120^{\circ} 23^{\prime} \mathrm{E}$ ), with the total area and average water depth of $446 \mathrm{~km}^{2}$ and $7 \mathrm{~m}$, respectively. The bay mouth is very narrow ( $3 \mathrm{~km}$ ) between Tuandao and Xuejiadao, and is connected to the Yellow Sea. There are dozens of rivers including Dagu River, Haibo Rriver, Licun Rriver, and Loushan Rriver etc., all of which are seasonal rivers [11-12].

The investigation on Cd in Jiaozhou Bay was carried on in April and July 1988 in five monitoring sites (i.e., 35, 36, 84, 85, and 90) (Fig. 1). Cd in waters was sampled and monitored follow by National Specification for Marine Monitoring [13]. 


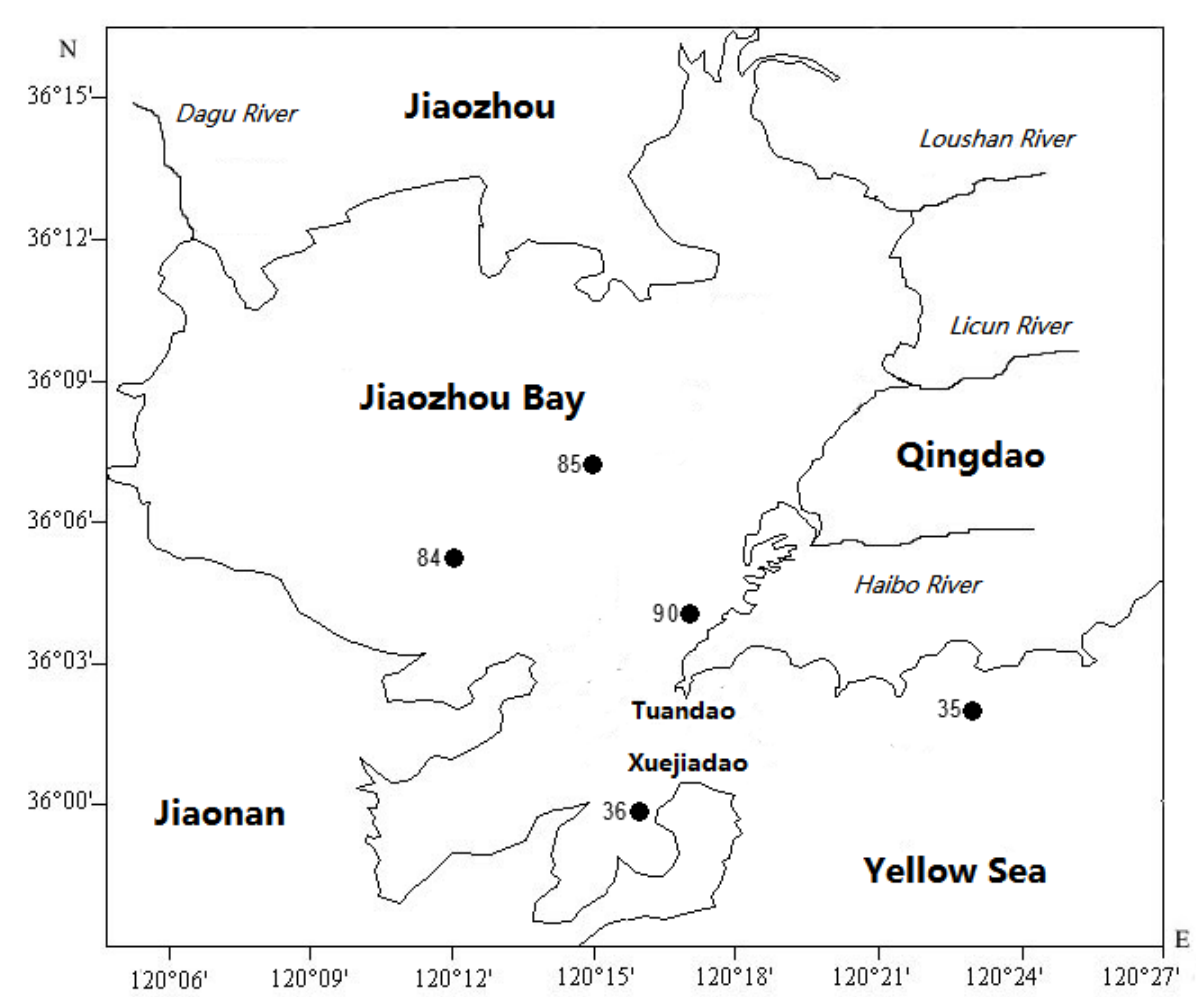

Fig. 1 Geographic location and sampling sites of Jiaozhou Bay

\section{Results and discussions}

\subsection{Vertical changes of $\mathrm{Cd}$ contents in surface and bottom waters.}

In order to assess the vertical variations, Cd contents in surface waters were subtracted from which in bottom waters, the minus are taken as the indexes. Sites 35, 36, 84, 85, and 90 were located in outside of the bay mouth, bay mouth, southwest of the bay, bay center, and inner side of the bay mouth, respectively. Positive and negative means $\mathrm{Cd}$ contents in surface waters were higher and lower than in bottom waters, respectively, while zero means Cd contents in surface waters were equal to in bottom waters (Table 1). The differences in sites 35, 36, 84, 85, and 90 in April and July 1988 were ranged from -0.04 to $0.36 \mu \mathrm{g} \mathrm{L}^{-1}$.

Table 1 The minus of Cd contents between surface and bottom waters in 1988

\begin{tabular}{lccccc}
\hline $\begin{array}{l}\text { Sampling } \\
\text { site }\end{array}$ & 35 & 36 & 84 & 85 & 90 \\
\hline $\begin{array}{l}\text { April } \\
\text { July }\end{array}$ & Positive & Negative & Negative & $\begin{array}{c}\text { Zero } \\
\text { Positive }\end{array}$ & Positive \\
\hline
\end{tabular}

\subsection{Regional settlement of $\mathrm{Cd}$ contents.}

In the sampling sites, the minus was changing with time, indicating the changes of Cd contents in surface and bottom waters. Once Cd was input to Jiaozhou Bay, Cd was originally entering into surface waters, and then was settling to bottom waters rapidly and continuously, resulting in the changes of Cd contents in surface and bottom waters. In April, Cd was mainly sourced from marine current whose source strength was relative weak. The input path was from the outer side of the bay mouth to the inner side of the bay mouth, as a result, Cd contents in surface waters were higher than those in bottom waters in the outer side of the bay mouth. Once Cd was arriving at the inner side of the bay mouth, a big part of Cd in surface waters had been settling to sea bottom, Cd in surface waters were higher than in bottom waters. The center of the bay was far away from the source and was not affected by the source input, and therefore, Cd contents in surface waters and bottom waters 
were homogeneous. In July, Cd was mainly sourced from river flow whose source strength was relative strong. The input path was from the estuary of the major river to all around. Hence, in the estuary, Cd contents in surface waters were higher than in bottom waters in the outer side of the bay mouth. Once Cd was arriving at the southwest of the bay mouth, a big part of Cd in surface waters had been settling to sea bottom, the Cd in surface waters was higher than in bottom waters.

\subsection{The temporal changes of the settlement process of $\mathrm{Cd}$.}

In the bay center, Cd contents in surface waters were closed to which in bottom waters in April, while in July Cd contents in surface waters were higher than in bottom waters. The reason was that the major source input of Cd from marine current had not arrived at the bay center in April, and waters in the bay centers was not affected by marine current, and therefore, Cd contents in this region were homogeneous. In July, Cd was mainly sourced from river flow in the inner side of the bay mouth. The flow direction of the river flow was pointing at the bay center, and therefore, $\mathrm{Cd}$ contents were higher than in bottom waters in the bay center.

\subsection{The spatial changes of the settlement process of $\mathrm{Cd}$.}

In April 1988, Cd contents in surface waters were higher than in bottom waters in the outer side of the bay mouth, while in the bay mouth, Cd contents in surface waters were lower than in bottom waters. This revealed that Cd was mainly sourced from the open waters, and Cd contents in surface waters were higher than in bottom waters. The source input of Cd was moving forward to the bay mouth, and the settlement was going on, Cd contents in surface waters were lower than in bottom waters. In the bay center, the waters were not influenced by source input, and therefore, Cd contents in waters were homogeneous. In July 1988, in the bay center and the inner side of the bay mouth, Cd contents in surface waters were higher than in bottom waters, while in the southwest of the bay $\mathrm{Cd}$ contents in surface waters were lower than in bottom waters. This revealed that Cd was mainly sourced from river flow, and in the estuary, inner side of the bay mouth, and the bay center, Cd contents in surface waters were higher than in bottom waters. In waters in the southwest of the bay, once a big part of Cd was transported to sea bottom, Cd contents in surface waters were lower than in bottom waters.

\subsection{Time and space states of the settlement process of $\mathrm{Cd}$.}

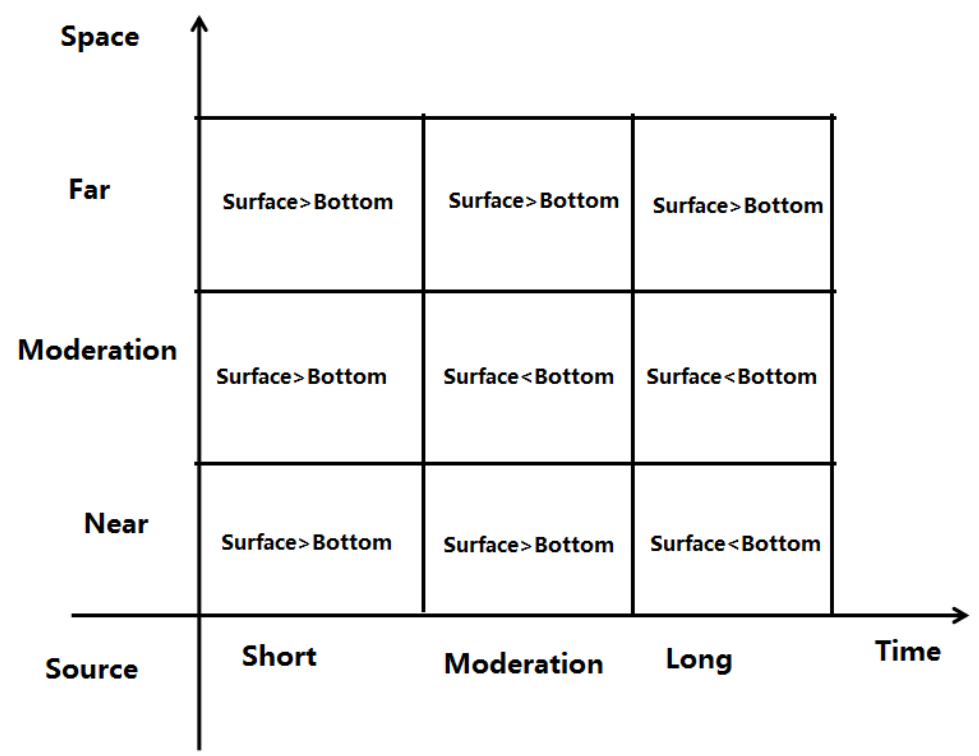

Fig. 2 Spatial and temporal states in Cd's settlement processes

During the settlement process of $\mathrm{Cd}$, there were three time states at temporal scale, and three space states at spatial scale. At temporal scale, there were three states in settling processes of Cd. 1) The source input of $\mathrm{Cd}$ was started, the settlement of $\mathrm{Cd}$ was just beginning, there was little 
accumulation of $\mathrm{Cd}$ in bottom waters, Cd contents in bottom waters was relative low, and as a result Cd contents in surface waters were higher than in bottom waters. 2) The source input of Cd was abundant, the accumulation of $\mathrm{Cd}$ in bottom waters was increasing after continuous sedimentation, Cd contents in bottom waters was relative high, and as a result Cd contents in bottom waters were higher than in surface waters. 3) The source input of Cd was continued, the Cd contents were homogeneously mixing, and as a result Cd contents in bottom waters were consist with in surface waters. At spatial scale, there were also three states in settling processes of Cd. 1) The source input of Cd was started, and in waters closed to the Cd sources, Cd contents in surface waters were higher than in bottom waters. 2) The source input of Cd was abundant, in waters along with the transport path of Cd source, Cd contents in bottom waters were higher than in surface waters. 3) The source input of Cd was continued, in waters far away the Cd source, the Cd contents were homogeneously mixing, and as a result $\mathrm{Cd}$ contents in bottom waters were consist with in surface waters. Taken time as X-coordinate, and space as y-coordinate, a block diagram model was provided to described the time and space states that there were nine states during the actual settlement process (Fig. 2).

\section{Conclusions}

In different regions, the minus of $\mathrm{Cd}$ contents between surface waters and bottom waters were changing along with time, and were indicating the changes of Cd contents in surface and bottom waters. Once Cd was inputting to Jiaozhou Bay, Cd was originally entering into surface waters, and then was settling to bottom waters rapidly and continuously, resulting in the changes of Cd contents in surface and bottom waters.

During the settlement process of $\mathrm{Cd}$, there were three time states at temporal scale, and three space states at spatial scale. Taken time as $\mathrm{x}$-coordinate, and space as y-coordinate, a block diagram model was provided to describe the time and space states that there were nine states during the actual settlement process. The changes of $\mathrm{Cd}$ contents in surface and bottom waters were determined by the strength of the source input and the distance of the transport path.

\section{Acknowledgements}

This research was sponsored by Doctoral Degree Construction Library of Guizhou Nationalities University, the China National Natural Science Foundation (31560107) and Research Projects of Guizhou Nationalities University ([2014]02), Research Projects of Guizhou Province Ministry of Education (KY [2014] 266), Research Projects of Guizhou Province Ministry of Science and Technology (LH [2014] 7376).

\section{References}

[1] Yang DF and Miao ZQ: Marine Bay Ecology (I): Beijing, Ocean Precess, (2010), p. 1-320. (in Chinese)

[2] Yang DF and Gao ZH: Marine Bay Ecology (II): Beijing, Ocean Precess, (2010), p. 1-330. (in Chinese)

[3] Yang DF, Chen Y, Wang H, et al.: Coastal Engineering, Vol. 29 (2010), p. 73-82.

[4] Yang DF, Chen Y, Liu CX, et al.: Coastal Engineering, Vol. 32(2013), p. 68-78.

[5] Yang DF, Zhu SX, Wu YF, et al.: Applied Mechanics and Materials, Vol.644-650 (2014), p. 5325-5328.

[6] Yang DF, Wang FY, Wu YF, et al.: Applied Mechanics and Materials, Vol.644-650 (2014), p. 5329-5312.

[7] Yang DF. Chen Y, Gao ZH, et al.: Proceedings of the 2015 international symposium on computers and informatics. Vol. (2015), p. 2667-2674. 
[8] Yang DF, Wang FY, He HZ, et al.: Proceedings of the 2015 international symposium on computers and informatics, 2015, p. 2655-2660.

[9] Yang DF, Wang FY, Zhao XL, et al.: Sustainable Energy and Enviroment Protection, 2015, p. 191-195.

[10] Yang DF, Wang FY, Yang XQ, et al.: Advances in Computer Science Research, Vol. 2352 (2015), p. 198-204.

[11] Yang DF, Chen Y, Gao ZH, et al.: Chinese Journal of Oceanology and Limnology, Vol. 23(2005), p. 72-90. (in Chinese)

[12] Yang DF, Wang FY, Gao ZH, et al. Marine Science, Vol. 28 (2004), p. 71-74.

[13] China's State Oceanic Administration: The specification for marine monitoring (Ocean Press, Beijiang 1991), p.1-300. (in Chinese) 